\title{
Pengaruh Pemberian Mulsa Alang-Alang dan Pupuk NPK Phonska Terhadap Pertumbuhan dan Produksi Tanaman Tomat (Solanum lycopersicum)
}

\author{
Said A. R. Assagaf $1{ }^{\bowtie}$ \\ ${ }^{1}$ Universitas Iqra Buru Fakultas Pertanian dan Kehutanan Program Studi Agroteknologi, Namlea, Indonesia \\ Email : saidabdurahmanasegaf@gmail.com

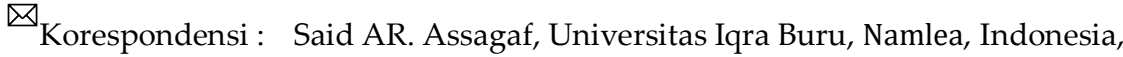 \\ Email : saidabdurahmanasegaf@gmail.com
}

\begin{abstract}
ABSTRAK.
Penelitian ini dilaksanakan pada bulan Agustus - November 2019 di Desa Namlea, dengan tujuan untuk mengetahui pemberian musa alang-alang serta NPK Phonska berbagai takaran agar menghasilkan Hasil terbaik dari Tanaman Tomat (Solanum lycopersicum). Penelitian ini dilakukan dengan menggunakan rancangan acak kelompok (RAK) yang terdiri dari dua faktor yaitu faktor pemberian Mmulsa alangalang dan faktor pemberian pupuk NPK ponska. Faktor pertama adalah mulsa (M) yang terdiri atas 3 taraf perlakuan yaitu M0 = Tanpa mulsa, M1 = Dengan ketebalan 2 $\mathrm{cm}, \mathrm{M} 2=$ Dengan ketebalan $4 \mathrm{~cm}$. Faktor kedua adalah pupuk Npk ponska (P) yang terdiri atas 4 taraf perlakuan yakni P0 $=$ tanpa pupuk Npk (control), $\mathrm{P} 1=200 \mathrm{Kg} / \mathrm{Ha}$ setara dengan 5 Gram/Tanaman, P2 $=300 \mathrm{Kg} /$ Hasetara dengan 7,5 Garam/Tanaman. Hasil Penelitian di dapat bahwa pada pemberian mulsa alang dengan ketebalan $4 \mathrm{~cm}$ perpetak bepengaruh sangat nyata terhadap pertumbuhan dan produksi tanaman tomat. Pada Pemberian pupuk NPK Phonska dengan dosis $300 \mathrm{Kg} / \mathrm{Ha}$ setara dengan 7,5 Gram/Tanamanberpengaruh sangat nyata terhadap pertumbuhan dan produksi tanaman tomat. Interaksi antara mulsa alang dengan ketebalan $4 \mathrm{~cm}$ perpetak dan pupuk NPK Phonska dengan dosis P2 $=300 \mathrm{Kg} / \mathrm{Ha}$ setara dengan 7,5 Gram/Tanaman berpengaruh sangat nyata terhadap pertumbuhan dan produksi tanaman tomat.
\end{abstract}

\section{Keyword: Pertumbuhan Tomat, NPK ponska, Solanum lycopersicum}

\section{PENDAHULUAN}

Tomat (Solanum lycorpersicum) berasal dari benua Amerika yang tersebar dari America Tengah hingga Amerika Selatan. Tomat pertama kali dibudidayakan oleh suku Inca dan suku Aztec pada tahun 700 SM. Penyebaranya sampai di Indonesia dimulai dari Filipina dan negara - negara Asia lainya pada abad ke-18 (Tugiyono, 2006)

Buah tomat mempunyai peran yang sangat besar dalam kehidupan sehari-hari . Tidakhanya sebagai bahan makanan tetapi juga bermanfaat sebagai obat-obatan dan kosmetik. Sebagai bahan makanan buah tomat bisa di konsumsi langsung, juga di gunakan sebagai pelengkap lalapan dan sebagai salah satu bumbu masakan, juga menjadi salah satu bahan baku industry di antaranya industri aneka minuman (juice), zat pewarna, saus dan lain sebagainya, disamping itu tomat mempunyai nilai gizi tinggi karena tomat kaya dengan fosfor, kalsium, besi, belerang, protein, vitamin A, B, dan C. Sebagai bahan obat-obatan, tomat mempunyai khasiat untuk mengobati berbagai macam penyakit.Tomat bermanfaat untuk, memmbersihkan darah dan liver, mencegah usus buntu, mengatasi gusi berdarah, sembelit, menyembuhkan influenza, diabetes mellitus, kulit bengkak akibat keracunan, bisul di mulut dan perut, wasir, radang prostal, lemah syahwat, dan meningkatkan kesuburan.Sebagai bahan kosmetik, tomat bermanfaat untuk merawat kecantikan wajah dan kulit.Kandungan tomatine pada tomat mempunyai khasiat sebagai anti radang, disampimg itu tomat mengandung kroten dan vitramin C yang berkhasiat sebagai antioksidan (Suraningsih, 2009). 
Mengingat manfaat buah tomat yang sedemikian banyak, maka permintaan terhadap komoditas ini sangat tinggi. Buah tomat dan olahannya sangat di sukai oleh anak-anak maupun dewasa, dari golongan masyarakat dengan tingkat perekonomian rendah sampai golongan masyarakat dengan tingkat perekonomian tinggi dan dibutuhkan dalam jumlah besar dan berkelanjutan. Masalah yang sering dihadapi dalam budidaya tanaman tomat, diantaranya adalah penurunan kualitas tomat yang disebabkan oleh seleksi benih yang kurang baik dan teknik budidaya yang belum sepenuhnya diterapkan.Kualitas produksi tomat yang baik sangat tergantung dari petani dan pengusaha pertanian di Indonesia, karena tanaman tomat memang membutuhkan perawatan secara khusus.Untuk meningkatkan kualitas dan kuantitas produksi tomat diperlukan usaha perluasan penanaman serta inovasi dalam teknologi budidaya tomat.(Wiryanta, 2002).

Dewasa ini pengembangan budidaya tomat merupakan salah satu andalan bagi pengingkatan pendapatan petani.Hal ini tepat sekali jika dikembangkan dikabupaten Buru, khususnya dikecamatan Namlea. Masalah yang dihadapi dalam pengembangan tanaman tomat adalah masih rendahnya produksi yang dicapai petani. Rendahnya hasil disebabkan oleh budidaya yang kurang baik (tanpa pemupukan dan penyiangan), persedian air kurang cukup (Rukmana, 1997).

Marzuki dan Suprapto (2005) menyatakan bahwa, kebutuhan air bagi tanaman berbeda-beda sesuai periode pertumbuhanya. Air berguna sebagai pembentuk protoplasma, pelarut, media pengangkut hara, media berlangsungnya reaksi-reaksi metabolism, bahan baku foto sintesis dan pengaruh dalam fase pemanjangan serta proses pertumbuhan.

Untuk mengatasi persediaan dalam tanah maka perlu penggunaan mulsa. Penggunaan mulsa dapat memberikan keuntungan antara lain , menghemat penggunaan air dan menguranggi kekeringan pada permukaan lahan, menjaga kelembaban tanah, memperkecil fluktuasi suhu tanah sehingga menguntungkan permukaan akar dan mikroorganisme tanah, memperkecil laju erosi tanah baik akibat tumbukan butir-butir hujan maupun aliran permukaan dan menekan pertumbuhan gulma dan penyakit serta menambah kandungan bahan organik dalam tanah (Rukmana 2006).

Selain pemberian mulsa, peningkatan produksi tanaman tomat dapat dilakukan dengan pemberian pupuk .menurut Setyamidjaja (1986), pupuk adalah semua bahan yang diberikan kepada tanah dengan maksud untuk memperbaiki sifat-sifat fisiska, kimia maupun biologi tanah, yang menurut proses terjadinya terdiri atas pupuk alam (organik), dan pupuk buatan (anorgnik).

Secara umum dapat dikatakan bahwa manfaat pupuk adalah menyediakan unsur hara yang kurang bahkan tidak tersedia ditanah untuk mendukung pertumbuhan tanaman. Disamping itu pupuk bermanfaat memperbaiki struktur tanah dari padat menjadi gembur, dan dapat menyediakan unsure hara yang dibutuhkan oleh tanaman .(Marsono, dkk 2001). Berdasarkan uraian diatas, maka dianggap perlu melaksanakan penelitian untuk mempelajari dan mengetahui pengaruh pemberian mulsa alang - alang dan pupuk NPK ponska terhadap pertunbuhan dan produksi tanaman tomat. Penelitian ini diharapkan berguna sebagai bahan informasi kepada petani dan instansi terkait dalam usaha peningkatan produksi tanaman tomat.

\section{II.METODE PENELITIAN}

Penelitian ini dilaksanakan pada bulan Agustus - November 2019 terhitung sejak persiapan media pertanaman hingga panen dan berlokasi di Desa Namlae , Kec Namlea, Kab buru. Bahan yang digunakan dalam penelitian ini adalah benih tomat, mulsa dan pupuk npk ponska. Alat-alat yang digunakan dalam penelitian ini adalah cangkul, parang babat, gembor, hand sprayer, meteran, kamera, ember, palu, paku, timbngan analitik, papan plat sampel, alat tulis, penggaris / mistar, kalkulator, dan lainya yang dianggap perlu.

Penelitian ini dilakukan dengan menggunakan rancangan acak kelompok (RAK) yang terdiri dari dua faktor yaitu : faktor pemberian Mulsa alang-alang dan faktor pemberian pupuk NPK ponska. Faktor pertama adalah mulsa (M) yang terdiri atas 3 taraf perlakuan yaitu $\mathrm{M} 0=$ Tanpa mulsa, $\mathrm{M} 1=$ Dengan ketebalan $2 \mathrm{~cm}$, M2 = Dengan ketebalan $4 \mathrm{~cm}$ dan faktor kedua adalah pupuk NPK ponska (P) yang terdiri atas 4 taraf perlakuan yaitu $\mathrm{P} 0=$ tanpa pupuk Npk (control), $\mathrm{P} 1=200 \mathrm{Kg} / \mathrm{Ha}$ setara dengan 5 Gram/Tanaman, P2 = $300 \mathrm{Kg} /$ Hasetara dengan 7,5 Garam/Tanaman, Dari kedua faktor tersebut terdapat 9 kombinasi perlakuan.

Pengamatan yang dilakukan pada penelitian ini meliputi parameter : 
a. Tinggi Tanaman, Tinggi tanaman diukur dari permukaan tanah sampai ujung daun tertinggi, pengukuran dilakukan setelah tanaman berumur 2 minggu setelah tanam, dan diukur 2 minggu sekali.

b. Jumlah cabang, Jumlah cabang dihitung mulai dari pucuk yang sudah mengembang sempurna sampai daun terakhir paling bawah, perhitungan dilakukan bersama dengan pengukuran tinggi tanaman dan dihitung setiap 2 minggu sekali.

c. Jumlah Bunga, Jumlah bunga dihitung dari munculnya bunga, perhitungan dilakukan setiap 2 minggu sekali.

d. Jumlah Buah, Jumlah buah dihitung munculnya bakal buah, perhitungan buah ini tidak bisa dihitung dari munculnya bunga karena semua bunga belum tentu menjadi bakal buah dan dilakukan setiap 2 minggu sekali.

e. Berat Buah Segar, Berat buah basah produksi penimbangan berat segar produksi dilakukan setelah panen dengan menimbang bagian tanaman khusunya buah.

Data dianalisis dengan analisis ragam( ANOVA ), dan jika menunjukan yang nyata maka dilanjutkan dengan uji beda nilai jujur (BNJ) (Hanifah, 2001)

\section{HASIL DAN PEMBAHASAN}

\subsection{HASIL}

\section{a. Rekapitulasi Analisis Sidik Ragam}

Tabel 1. Rekapitulasi sidik ragam

\begin{tabular}{|c|c|c|c|c|c|}
\hline \multirow{2}{*}{ No } & \multirow{2}{*}{$\begin{array}{c}\text { Paramter } \\
\text { Pengamatan }\end{array}$} & \multicolumn{3}{|c|}{ Pengaruh perlakuan } & \multirow{2}{*}{$\begin{array}{l}\text { Interaksi } \\
\text { MP }\end{array}$} \\
\hline & & Kombinasi MP & M & $P$ & \\
\hline \multirow[t]{4}{*}{1} & Tinggi Tanaman & & & & \\
\hline & Umur 2 MST & $* *$ & $* *$ & $* *$ & $*$ \\
\hline & Umur 4 MST & $* *$ & $* *$ & $* *$ & $* *$ \\
\hline & Umur 6 MST & $* *$ & $* *$ & $* *$ & $* *$ \\
\hline \multirow[t]{4}{*}{2} & Jumlah cabang & & & & \\
\hline & Umur 2 MST & $* *$ & $* *$ & $* *$ & $*$ \\
\hline & Umur 4 MST & $* *$ & $* *$ & $* *$ & $* *$ \\
\hline & Umur 6 MST & $* *$ & $* *$ & $* *$ & $* *$ \\
\hline \multirow[t]{2}{*}{3} & Jumlah bunga & & & & \\
\hline & Umur 7 MST & $* *$ & $* *$ & $* *$ & $\operatorname{tn}$ \\
\hline 4 & Jumlah buah & $* *$ & $* *$ & $* *$ & $\operatorname{tn}$ \\
\hline 5 & Berat buah segar & $* *$ & $* *$ & *** & $\operatorname{tn}$ \\
\hline
\end{tabular}

Dari hasil tabel tersebut diketahui bahwa kombinasi MP pada parameter tinggi tanaman, jumlah cabang, jumlah bunga, jumlah buah dan berat buah segar berpengaruh sangat nyata, kemudian untuk perlakuan M dana P juga berpengaruh sangat nyata, diinteraksi MP berpengaruh sangat nyata kecuali untuk tinggi tanaman umur 2 MST berpengaruh nyata dan untuk jumlah buah berpengaruh tidak nyata.

\section{b. Tinggi Tanaman 2 MST}

Tabel 1. Tinggi Tanaman (cm) Umur 2 MST.

\begin{tabular}{ccccc}
\hline Perlakuan & P0 & P1 & P2 & Rataan \\
\hline M0 & $21.33 \mathrm{a}$ & $21.4 \mathrm{a}$ & $31,13 \mathrm{~b}$ & $24.62 \mathrm{a}$ \\
M1 & $30.6 \mathrm{~b}$ & $32.8 \mathrm{~b}$ & $32.67 \mathrm{~b}$ & $32.02 \mathrm{a}$ \\
M2 & $34.4 \mathrm{~b}$ & $30.27 \mathrm{~b}$ & $34.33 \mathrm{~b}$ & $33 \mathrm{~b}$ \\
\hline Rataan & $\mathbf{2 8 . 7 7 ~ a}$ & $\mathbf{2 8 . 1 5 ~ a}$ & $\mathbf{3 2 . 7 1 ~ a}$ & \\
\hline BNJ (0.05) & & $\mathbf{7 . 5}$ & &
\end{tabular}

Keterangan : Angka-angka yang di ikuti oleh huruf yang sama berarti berbeda nyata pada taraf uji BNJ 0.05 
Hasil uji BNJ $(0,05)$ pada tabel 1 menunjukan bahwa perlakuan pemberian mulsa pada 2 mst ketebalan 4 CM (M2) memperlihatkan tinggi tanaman yang terbaik yaitu $33 \mathrm{~cm}$, berbeda sangat nyata dengan tanpa perlakuan (M0) sedangkan pada pemberian mulsa $2 \mathrm{~cm}$ (M1) tidak berbeda nyata.

Pada perlakuan pupuk NPK Phonska (P2) memperlihatkan tinggi tanamanyang terbaik P2 yaitu $32,71 \mathrm{~cm}$ berpengaruh tidak nyata pada semua perlakuan. Pada kombinasi perlakuan M2P2 memperlihatkan tinggi tanaman yang terbaik yaitu $34,33 \mathrm{~cm}$, berpengaruh tidak nyata pada perlakuan lainnya.

\section{c. Tinggi Tanaman 4 MST}

Tabel 2. Tinggi Tanaman (cm) Umur 4 MST

\begin{tabular}{|c|c|c|c|c|}
\hline Perlakuan & PO & P1 & P2 & Rataan \\
\hline M0 & $32.87 \mathrm{a}$ & $34.13 \mathrm{a}$ & $73.07 \mathrm{~b}$ & $46.69 \mathrm{a}$ \\
\hline M1 & $35.93 \mathrm{a}$ & $72.87 \mathrm{~b}$ & $72.27 \mathrm{~b}$ & $60.35 \mathrm{a}$ \\
\hline M2 & $42.27 \mathrm{a}$ & $66.8 \mathrm{~b}$ & $71.07 \mathrm{~b}$ & $60.04 \mathrm{a}$ \\
\hline Rataan & $32.02 a$ & $57.93 \mathrm{~b}$ & $72.13 \mathrm{~b}$ & \\
\hline$B N J(0.05)$ & & 20.81 & & \\
\hline
\end{tabular}

Hasil uji BNJ $(0,05)$ pada tabel 2 menunjukan bahwa perlakuan pemberian mulsa dengan ketebalan $2 \mathrm{~cm}$ (M1) memperlihatkan tinggi tanaman yang terbaik yaitu 60,35 cm, berbeda sangat nyata dengan tanpa perlakuan (M0) sedangkan pada pemberian mulsa $4 \mathrm{~cm}$ (M2) tidak berbeda nyata.

Pada perlakuan pupuk NPK Phonska (P2) memperlihatkan tinggi tanaman yang terbaik P2 yaitu 72,13 cm berpengaruh tidak nyata pada semua perlakuan. Pada kombinasi perlakuan M1P1 memperlihatkan tinggi tanaman yang terbaik yaitu $72,87 \mathrm{~cm}$, berpengaruh tidak nyata pada M1P2 dan M2P2 berbeda nyata pada M2P1.

\section{d. Tinggi Tanaman 6 MST}

Tabel 3. Tinggi Tanaman (cm) Umur 6 MST

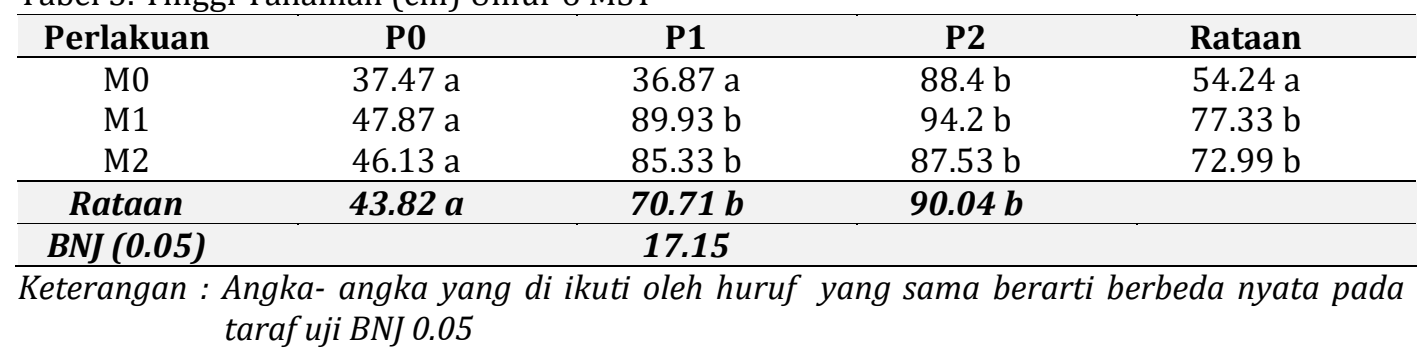

Hasil uji BNJ $(0,05)$ pada tabel 3 menunjukan bahwa perlakuan pemberian mulsa dengan ketebalan $2 \mathrm{~cm}$ (M1) memperlihatkan tinggi tanaman yang terbaik yaitu 77,33 cm, berbeda sangat nyata dengan tanpa perlakuan (M0) sedangkan pada pemberian mulsa $4 \mathrm{~cm}$ (M2) tidak berbeda nyata.

Pada perlakuan pupuk NPK Phonska (P2) memperlihatkan tinggi tanaman yang terbaik P2 yaitu 90,04 cm berpengaruh tidak nyata pada semua perlakuan. Pada kombinasi perlakuan M1P2 memperlihatkan tinggi tanaman yang terbaik yaitu $94,2 \mathrm{~cm}$, berpengaruh tidak nyata pada M1P1, M2P2 dan M2P1.

\section{e. Jumlah cabang 2 MST}

Tabel 4. Jumlah cabang (cm) Umur 2 MST

\begin{tabular}{|c|c|c|c|c|}
\hline Perlakuan & PO & P1 & P2 & Rataan \\
\hline M0 & $10.73 \mathrm{a}$ & $8 \mathrm{a}$ & $10.6 \mathrm{a}$ & $9.77 \mathrm{a}$ \\
\hline M1 & $10.73 \mathrm{a}$ & $19.07 \mathrm{~b}$ & $19.47 \mathrm{~b}$ & $16.42 \mathrm{a}$ \\
\hline M2 & $11.8 \mathrm{~b}$ & $18.93 \mathrm{~b}$ & $23.2 \mathrm{~b}$ & $17.97 \mathrm{a}$ \\
\hline Rataan & $11.08 a$ & $15.33 a$ & $17.75 b$ & \\
\hline BNJ $(0.05)$ & & 9.30 & & \\
\hline
\end{tabular}


Hasil uji BNJ $(0,05)$ pada tabel 4 menunjukan bahwa perlakuan pemberian mulsa dengan ketebalan $4 \mathrm{~cm}$ (M2) memperlihatkan jumlah cabang yang terbaik yaitu 17,97 cm, berbeda sangat nyata dengan tanpa perlakuanl (M0) sedangkan pada pemberian mulsa $2 \mathrm{~cm}$ (M1) tidak berbeda nyata.

Pada perlakuan pupuk NPK Phonska (P2) memperlihatkan jumlah cabang yang terbaik P2 yaitu $17,75 \mathrm{~cm}$ berpengaruh tidak nyata pada semua perlakuan. Pada kombinasi perlakuan M2P2 memperlihatkan jumlah cabang yang terbaik yaitu $23,2 \mathrm{~cm}$, berpengaruh tidak nyata pada M1P1, M1P2 dan M2P1.

\section{f. Jumlah cabang 4 MST}

Tabel 5. Jumlah cabang (cm) Umur 4 MST

\begin{tabular}{ccccc}
\hline Perlakuan & P0 & P1 & P2 & Rataan \\
\hline M0 & $13.07 \mathrm{a}$ & $15.67 \mathrm{a}$ & $14.2 \mathrm{a}$ & $14.31 \mathrm{a}$ \\
M1 & $12.33 \mathrm{a}$ & $21.87 \mathrm{~b}$ & $22.6 \mathrm{~b}$ & $18.93 \mathrm{a}$ \\
M2 & $13.73 \mathrm{a}$ & $22.53 \mathrm{~b}$ & $25.47 \mathrm{~b}$ & $20.57 \mathrm{a}$ \\
\hline Rataan & $\mathbf{1 3 . 0 4 ~ a}$ & $\mathbf{2 0 . 0 2 ~} \mathbf{b}$ & $\mathbf{2 0 . 7 5 ~} \mathbf{b}$ & \\
BNJ (0.05) & & $\mathbf{5 . 6 8}$ & & \\
\hline \multicolumn{2}{r}{ Keterangan : Angka- angka yang di ikuti oleh huruf } \\
taraf uji BNJ 0.05
\end{tabular}

Hasil uji BNJ $(0,05)$ pada tabel 5 menunjukan bahwa pemberian mulsa dengan ketebalan 4 cm (M2) memperlihatkan jumlah cabang yang terbaik yaitu 20,57 cm, berbeda sangat nyata dengan tanpa perlakuan (M0) dan M1

Pada pupuk NPK Phonska (P2) memperlihatkan jumlah cabang yang terbaik yaitu 20,75 cm berpengaruh tidak nyata pada semua perlakuan. Pada kombinasi perlakuan M2P2 memperlihatkan jumlah cabang yang terbaik yaitu 25,47 cm, berpengaruh tidak nyata pada M1P1, M1P2 dan M2P1.

\section{g. Jumlah Cabang 6 MST}

Tabel 6. Jumlah cabang (cm) Umur 6 MST

\begin{tabular}{|c|c|c|c|c|}
\hline Perlakuan & PO & P1 & P2 & Rataan \\
\hline M0 & $17.67 \mathrm{a}$ & $19.47 \mathrm{a}$ & $18.53 \mathrm{a}$ & $18.55 \mathrm{a}$ \\
\hline M1 & $16.33 \mathrm{a}$ & $28.87 \mathrm{~b}$ & $26.47 \mathrm{~b}$ & $23.89 \mathrm{~b}$ \\
\hline M2 & $17 \mathrm{a}$ & $29 \mathrm{~b}$ & $32.6 \mathrm{~b}$ & $26.2 \mathrm{~b}$ \\
\hline Rataan & $17 a$ & $25.78 \mathrm{~b}$ & $25.86 \mathrm{~b}$ & \\
\hline$B N J(0.05)$ & & 4.57 & & \\
\hline
\end{tabular}

Hasil uji BNJ $(0,05)$ pada tabel 6 menunjukan bahwa perlakuan pemberian mulsa dengan ketebalan $4 \mathrm{~cm}$ (M2) memperlihatkan jumlah cabang yang terbaik yaitu 26,2 cm, berbeda sangat nyata dengan tanpa perlakuan (M0) dan (M1).

Pada perlakuan pupuk NPK Phonska (P2) memperlihatkan jumlah cabang yang terbaik P2 yaitu 25,86 cm berpengaruh tidak nyata pada perlakuan (P1) dan berbeda nyata dengan tanpa perlakuan. Pada kombinasi perlakuan M2P2 memperlihatkan jumlah cabang yang terbaik yaitu 32,6 $\mathrm{cm}$, berpengaruh tidak nyata pada M1P1, M1P2 dan M2P1.

\section{h. Jumlah Bunga 7 MST}

Tabel 7. Jumlah Bunga (cm) Umur 7 MST

\begin{tabular}{|c|c|c|c|c|}
\hline Perlakuan & P0 & P1 & P2 & Rataan \\
\hline M0 & $12.73 \mathrm{a}$ & $18.73 \mathrm{a}$ & $27.47 \mathrm{a}$ & $19.64 \mathrm{a}$ \\
\hline M1 & $22.67 \mathrm{a}$ & $35 \mathrm{a}$ & $37 \mathrm{a}$ & $31.55 \mathrm{a}$ \\
\hline M2 & $25.87 \mathrm{a}$ & $36.33 \mathrm{a}$ & $45.07 \mathrm{a}$ & $35.75 \mathrm{a}$ \\
\hline Rataan & $20.42 a$ & $30.02 a$ & $36.51 a$ & \\
\hline$B N J(0.05)$ & & 15.64 & & \\
\hline
\end{tabular}


Hasil uji BNJ $(0,05)$ pada tabel 7 menunjukan bahwa perlakuan pemberian mulsa dengan ketebalan $4 \mathrm{~cm}$ (M2) memperlihatkan jumlah bunga yang terbaik yaitu 35,75 cm, berbeda sangat nyata dengan tanpa perlakuan (M0) sedangkan pada pemberian mulsa $2 \mathrm{~cm}$ (M1) tidak berbeda nyata.

Pada perlakuan pupuk NPK Phonska (P2) memperlihatkan jumlah bunga yang terbaik P2 yaitu $36,51 \mathrm{~cm}$ berpengaruh tidak nyata pada semua perlakuan. Pada kombinasi perlakuan M2P2 memperlihatkan jumlah bunga yang terbaik yaitu $45,07 \mathrm{~cm}$, berpengaruh tidak nyata pada M1P1, M1P2 dan M2P1.

\section{i. Jumlah Buah}

Tabel 8. Jumlah Buah (cm) pada pemberian mulsa dan pupuk NPK Phonska

\begin{tabular}{ccccc}
\hline Perlakuan & P0 & P1 & P2 & Rataan \\
\hline M0 & $13.67 \mathrm{a}$ & $23.93 \mathrm{a}$ & $21.93 \mathrm{a}$ & $19.84 \mathrm{a}$ \\
M1 & $18.13 \mathrm{a}$ & $26.87 \mathrm{a}$ & $28.87 \mathrm{a}$ & $24.62 \mathrm{a}$ \\
M2 & $24.67 \mathrm{a}$ & $29.27 \mathrm{a}$ & $34.33 \mathrm{a}$ & $29.42 \mathrm{a}$ \\
\hline Rataan & $\mathbf{1 8 . 8 2} \mathbf{a}$ & $\mathbf{2 6 . 6 9}$ & $\mathbf{2 8 . 3 7}$ & \\
\hline BNJ (0.05) & & $\mathbf{1 3 . 4 3}$ & & \\
\hline Keterangan : Angka- angka yang di ikuti oleh huruf & yang & berarti berbeda nyata pada taraf uji \\
& BNJ 0.05
\end{tabular}

Hasil uji BNJ $(0,05)$ pada tabel 8 menunjukan bahwa perlakuan pemberian mulsa dengan ketebalan $4 \mathrm{~cm}$ (M2) memperlihatkan jumlah buah yang terbaik yaitu 29,42 cm, berbeda sangat nyata dengan tanpa perlakuan (M0) sedangkan pada pemberian mulsa $2 \mathrm{~cm}$ (M1) tidak berbeda nyata.

Pada perlakuan pupuk NPK Phonska (P2) memperlihatkan jumlah buah yang terbaik P2 yaitu $28,37 \mathrm{~cm}$ berpengaruh tidak nyata pada semua perlakuan. Pada kombinasi perlakuan M2P2 memperlihatkan jumlah buah yang terbaik yaitu $34,33 \mathrm{~cm}$, berpengaruh tidak nyata pada M1P1, M1P2 dan M2P1.

\section{j. Berat Buah Segar}

Tabel 9. Berat buah segar pada pemberian mulsa dan pupuk NPK Phonska

\begin{tabular}{ccccc}
\hline Perlakuan & P0 & P1 & P2 & Rataan \\
\hline M0 & $1.09 \mathrm{a}$ & $2.03 \mathrm{~b}$ & $1.88 \mathrm{~b}$ & $1.67 \mathrm{a}$ \\
M1 & $1.59 \mathrm{a}$ & $1.92 \mathrm{~b}$ & $2.80 \mathrm{~d}$ & $2.13 \mathrm{~b}$ \\
M2 & $2.42 \mathrm{c}$ & $3.07 \mathrm{e}$ & $4.05 \mathrm{f}$ & $3.18 \mathrm{~b}$ \\
\hline Rataan & $\mathbf{1 . 7 ~ a}$ & $\mathbf{2 . 3 4 ~ b}$ & $\mathbf{2 . 9 1 ~ b}$ & \\
\hline BNJ (0.05) & & $\mathbf{0 . 2 1}$ & & \\
\hline \multirow{2}{*}{ Keterangan : Angka- angka yang di ikuti oleh huruf } & yang & berarti berbeda nyata pada taraf uji \\
& BNJ 0.05
\end{tabular}

Hasil uji BNJ $(0,05)$ pada tabel 9 menunjukan bahwa perlakuan pemberian mulsa dengan ketebalan $4 \mathrm{~cm}$ (M2) memperlihatkan berat buah segar yang terbaik yaitu 3,18 berbeda sangat nyata dengan tanpa perlakuanl (M0) dan pada perlakuan (M1).

Pada perlakuan pupuk NPK Phonska (P2) memperlihatkan berat buah segar yang terbaik P2 yaitu $2,91 \mathrm{~cm}$. tidak berpengaruh nyata pada perlakuan (P1) dan berpengaruh nyata dengan tanpa perlakuan (P0). Pada kombinasi perlakuan M2P2 memperlihatkan berat buah segar yang terbaik yaitu 4,05 kg berpengaruh tidak nyata pada M1P1, M1P2 dan M2P1.

\subsection{Pembahasan}

Pemberian mulsa alang-alang memberikan pengaruh yang sangat nyata terhadap pertumbuhan tanaman tomat, baik pada tinggi tanaman,jumlah cabang, jumlah bunga, jumlah buah maupun berat buah segar. Pada pemberian mulsa dengan tebal $2 \mathrm{~cm}$ berpengaruh sangat nyata terhadap tinggi tanaman dari minggu ke 2 sampai minggu ke- 6 setelah taman, sedangkan mulsa dengan ketebalan $4 \mathrm{~cm}$ berpengaruh sangat nyata terhadap jumlah cabang, jumlah bunga, jumlah buah, dan berat buah segar. Hal ini terlihat jelas bahwa pemberian Mulsa alang-alang berpengaruh sangat nyata terhadap parameter yang diamati sesuai dengan keuntungan mulsa alang-alang berupa sisa-sisa tanaman menjadi sumber bahan organik tanah.hal ini menunjukan bahwa mulsa alang-alang mampu memenuhi pertumbuhan dan produksi tanaman tomat. (Purwowidodo, 2009).

tanaman tomat. 
Pemberian pupuk phonska memberikan pengaruh yang sangat nyata terhadap pertumbuhan tanaman tomat, baik pada tinggi tanaman,jumlah cabang, jumlah bunga, jumlah buah maupun berat buah segar. Pada pertumbuhan pupuk phonska dengan dosis $300 \mathrm{~kg} / \mathrm{Ha}$ setara dengan 7,5 gr/ Tanaman, berpengaruh sangat nyata terhadap semua parameter yang diamati hal ini menunjukan bahwa pemberian pupuk phonska dengan dosis $200 \mathrm{~kg} /$ Ha setara dengan $5 \mathrm{gr} /$ Tanaman, tidak cukup memenuhi kebutuhan pertumbuhan dan hasil produksi tanaman tomat.Hasil penelitian menunjukan bahwa perlakuan dengan dosis pupuk P2 yang mampu memenuhi kebutuhan tanaman tomat. Hal ini sesuai dengan manfaat pupuk phonska adalah meningkatkan produksi kualitas panen dan menambah daya tahan tanaman terhadap gangguan hama, penyakit, dan kekeringan sehingga membuat tanaman dapat tumbuh dengan baik.(http://www.petrokimia-gresik.com/phonska.asp.2016)

Hasil penelitian menunjukan bahwa pemberian Mulsa alang-alang yang berbeda dan pupuk NPK phonska memberikan pengaruh yang sangat nyata terhadap parameter yang diamati. Ini dapat dilihat pada parameter tinggi tanaman, jumlah cabang, jumlah bunga, jumlah buah, dan berat buah segar. Hal ini menunjukan bahwa Mulsa alang-alang dan pupuk ponska mampu memenuhi kebutuhan tanaman tomat untuk pertumbuhan dan produksinya pada lokasi penelitian tersebut.

\section{PENUTUP}

Pemberian mulsa alang dengan ketebalan $4 \mathrm{~cm}$ perpetak bepengaruh sangat nyata terhadap pertumbuhan dan produksi tanaman tomat, pada Pemberian pupuk NPK Phonska dengan dosis 300 $\mathrm{Kg} / \mathrm{Ha}$ setara dengan 7,5 Gram/Tanamanberpengaruh sangat nyata terhadap pertumbuhan dan produksi tanaman tomat dan Interaksi antara mulsa alang dengan ketebalan $4 \mathrm{~cm}$ perpetak dan pupuk NPK Phonska dengan dosis $\mathrm{P}_{2}=300 \mathrm{Kg} / \mathrm{Ha}$ setara dengan 7,5 Gram/Tanaman berpengaruh sangat nyata terhadap pertumbuhan dan produksi tanaman tomat. Perlu dilaksanakan penelitian lebih lanjut tentang bagaimana kombinasi antara pengguna mulsa alang dengan pupuk NPK Phonska dengan factor lain yang sesuai agar produksi tanaman tomat meningkat.

\section{DAFTAR PUSTAKA}

Tugiyono, 2006. Bertanam Tomat. Jakarta: Penebar Swadaya.

Suraningsih, 2009. Mari berkebun Tomat . Penerbit CV Sinar Cemerlang Abadi, Jakarta.

Wiryanta, 2002. Bertanam Tomat. Jakarta: Agro Mendia Pustaka.

Rukmana, 1997. Bercocok Tanaman Tomat. Kanisius, Yogyakarta.

Purwowidodo, 2009. Teknologi Mulsa. Dewaruci Press. Jakatra.

Sutedjo, 2006. Pupuk dan Cara Pemupukan. Rineka Cipta, Jakarta.

Djoehana,S. 1986. Pupuk dan Pemupukan. Penerbit CV Simplex, Jakarta.

( http ://www.petrokimia-gresik.com/phonska.asp.2016).

Nazarudin, 2000. Alat Penyiangan Kombinasi dengan Pembumbun Bertebaga Enjin Untuk Tanaman Tomat, p. 16 - 27 Dalam :Hasil Penelitian danPengembangan Alat Pertanian1999/2000. Balai Penelitian

Tanaman tomat dan Serealia Lain.

Nazarudin, 2000. Budidaya dan Pengaturan Panen Sayuran Dataran Rendah.Penebar Swadaya. Jakarta.

W.D.Herawati, 2012, Budidaya Sayuran. PT. Buku Kita, Yogyakarta. 